\title{
The Pathfinder
}

\author{
Ingrid Davis \\ davis@eine-welt-mvg.de
}

\begin{abstract}
Copyright $(\mathcal{} 2020$ Ingrid Davis. This text may be archived and redistributed both in electronic form and in hard copy, provided that the author and journal are properly cited and no fee is charged, in accordance with our Creative Commons Licence.
\end{abstract}

\begin{abstract}
An homage to the scholar, traveller and person Geoff Davis by his wife, Ingrid Davis.
\end{abstract}

Keywords: Geoff Davis, travelling as learning, sense of direction

Geoff proposed to me under a palm tree in Sydney Harbour on New Year's Eve 1995. We had been travelling around Australia for two months by the time we reached Sydney, and had been a couple for five years. It is telling, I suppose, that I agreed to marry him at (from our perspective) the other end of the world, even though we didn't know then just how often we would be visiting Australia and New Zealand in the years to come and how much we would come to love both countries.

Geoff was a world traveller, always just back from somewhere, and always on the way to somewhere else, his curiosity about other cultures, countries and their people was unending. I caught the travelling bug quite early on in our relationship and I'll be forever grateful for all the wonderful memories I have of our numerous trips across the globe.

Geoff never just travelled, he always explored. He would walk around for hours to familiarise himself with a new city; he would work out how to use the public transport system in a blink; and you could trust him to locate the best pubs and restaurants in no time. And he would talk to people, without prejudice and always prepared to listen - and learn. When Geoff came back from a trip, he would always talk about the fascinating conversations he had with people on trains, on busses, in pubs and everywhere else, really.

Geoff's sense of orientation was incredible. I'm convinced, if you had dropped him in the desert somewhere, he would have found his way home. I think people sensed this about him, because in a lot of places, tourists would actually come up to Geoff and ask him for 
directions - whether it was London, Berlin, Paris, Innsbruck or Amsterdam. And the mind-boggling thing is that he would know the answer in nine out of ten cases. I have called this piece 'The Pathfinder', because I think that is what he was, in all sorts of ways. He constantly found new paths in which academic research could and should move, and he helped people along on these paths as best he knew how. More practical pathfinding he did for his students - he was the only person in his Department who offered excursions for students, to Ireland, Wales, England or South Africa, thus opening a door into a new world for a lot of us. And it is certainly no coincidence that he joined an excursion to China organised by the Sociology department in 1978 - which was one of the first student trips allowed by the Chinese government. Geoff was there. Of course.

I don't think I have ever met anyone who was interested in and knowledgeable about so many different things - such as Art, Architecture, Languages, Literature, Film, Classical Music and Jazz, History and most of all Politics. Likewise, as a scholar he didn't specialise in one field or one country - he was simply too interested in the world and all its goings-on to limit himself to one field of expertise, one country or one genre.

If Geoff was addicted to anything, it was the News. No matter where he was, you would always see him with a newspaper under his arm or in his bag, and if he put on a TV, the first thing he would look for was the BBC or at a pinch CNN. While following the news from Europe and around the world, he would also read at least one newspaper from the country he was in at any one time. What was phenomenal, however, was how much of the information he absorbed, he actually retained. The breadth and depth of his knowledge on all sorts of things was truly amazing, and his memory simply unbelievable. Mind you, this was not limited to news or academic knowledge. If you travelled with Geoff, let's say through England, after turning one corner or another, he would say: "Oh, hang on, there's a pub around this bend. I had a fantastic meal there thirty years ago, let's see whether it's still there." And usually, it would be - whether it was restaurants, pubs or his second addiction: bookshops.

Geoff was a reader. You would hardly ever see him without a book, a magazine, a newspaper or - when on the road - a travel guide. He believed that as a university teacher it was his job to be aware and informed about the world and to be able to apply this knowledge to the study of literature. He was much more interested in the social, historical and political background of a literary work than he ever was in literary theory. He firmly believed that it was essential to be aware of the background and context of literature, and I think that this approach was what made his work so unique and interesting at a time when (to my outsider's view) literary theory seems to have taken over the academic discourse about literature. One of his favourite quotes was from one of his tutors at Oxford who must have said to him: "If I want to know what's in the secondary literature, I'll read it. I want to know what you think about it." Of course, he taught his students about the importance of secondary literature and the necessity to engage with the contributions of other scholars. But mainly his aim was to teach his students to think for themselves rather than just regurgitate what other people had already written. And I think that that is one of the reasons why he was so popular with his students. 
I think another reason for his popularity was his humility and modesty. To my mind it is an incredible achievement to have won a scholarship to Oxford University, especially for a boy from a very humble background in Northern England in the 1960s. But all he would ever say was: "There were so many people there who were so much more intelligent than me. I just worked very hard." Until his dying day Oxford the place and Oxford the university were very close to his heart, and he remained immensely grateful to have been given this chance. He achieved so much, did his doctorate in German Studies, his Habilitation in Post-Colonial Studies and his list of publications is roughly 50 pages (!) long - yet he never bragged. He moved academic studies forward significantly - yet he never needed the trappings of power for his ego. As a teacher he was always approachable for his students, and he loved engaging with intelligent young people and opening doors for them, be it through creating exchanges with other universities or by encouraging them to tackle unusual and interesting projects.

Geoff was not only a gentleman, he was also a gentle man, and it was almost impossible to pick a fight with him. He was passionate, about his work and about things that were wrong in our society - and he wouldn't only speak out against things that he thought to be wrong, but he would also try to do something about them. He wasn't one to stand idly by.

Looking back on his life, he would always say: "I've had an incredible run for my money." And yet, he wasn't ready to go. At 74 he was still working as though retirement hadn't happened, because he loved his work so much - and the first thing he said to the doctor who gave us the terrible diagnosis, was: "I haven't got time for this."

Pancreatic cancer is a bastard. Geoff was ready to fight it tooth and nail, but there was nothing anybody could do, and ultimately, he faced the final challenge of his life with stoicism and courage. I suppose the quiet times in heaven are over...

Aachen, Germany

March 2019 
Coolabah, $N r$ 28, 2020, ISSN 1988-5946, Observatori: Centre d'Estudis Australians $i$ Transnacionals / Observatory: Australian and Transnational Studies Centre,

Universitat de Barcelona

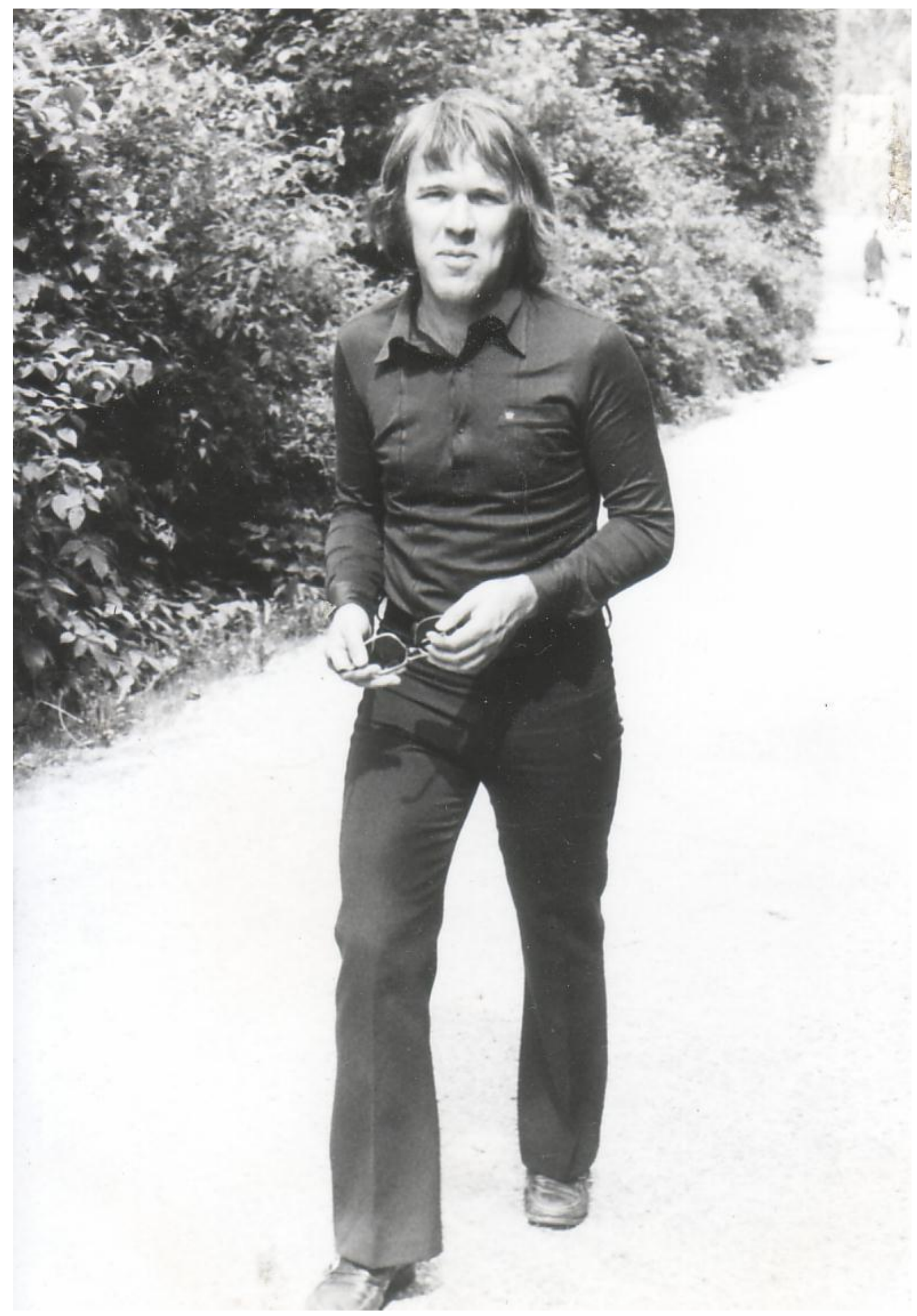

Geoff in the 1960s (C) Ingrid Davis 
Coolabah, $\mathrm{Nr}$ 28, 2020, ISSN 1988-5946, Observatori: Centre d'Estudis Australians $i$ Transnacionals / Observatory: Australian and Transnational Studies Centre,

Universitat de Barcelona

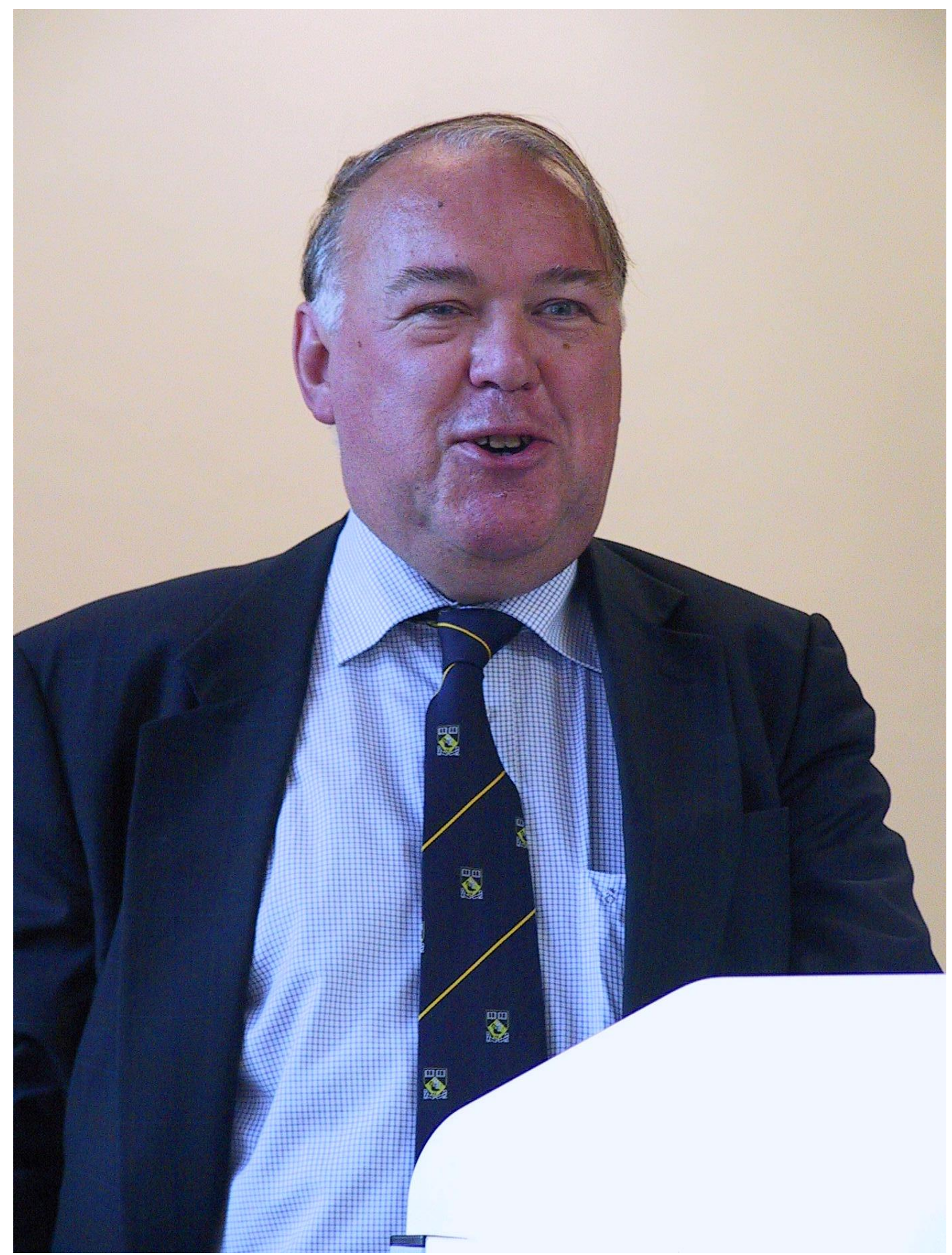

Geoff Lecture Habilitation 2000 @ Ingrid Davis 
Coolabah, $N r$ 28, 2020, ISSN 1988-5946, Observatori: Centre d'Estudis Australians $i$ Transnacionals / Observatory: Australian and Transnational Studies Centre,

Universitat de Barcelona

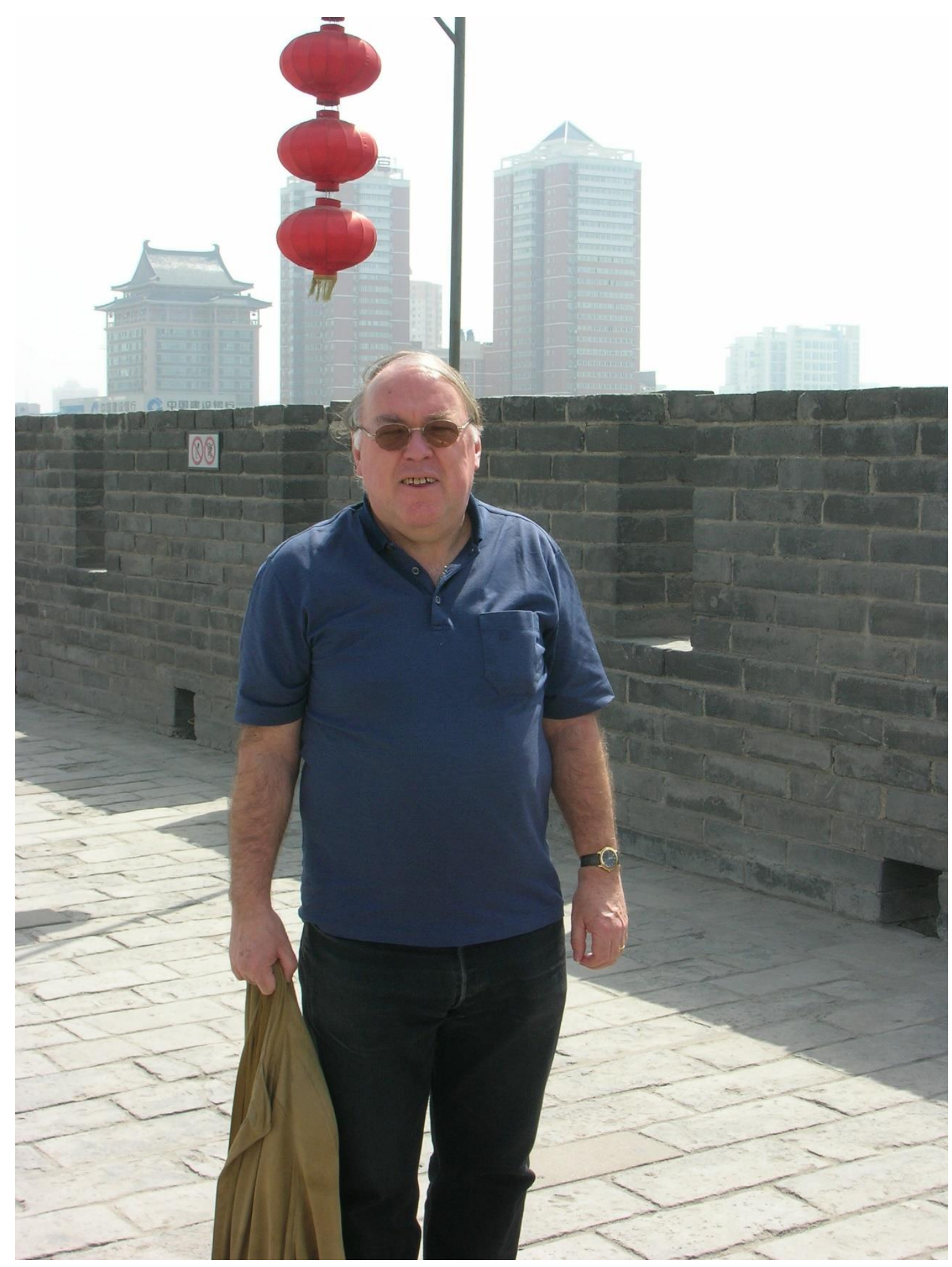

China 2006 C Ingrid Davis 
Coolabah, $N r$ 28, 2020, ISSN 1988-5946, Observatori: Centre d'Estudis Australians $i$ Transnacionals / Observatory: Australian and Transnational Studies Centre,

Universitat de Barcelona

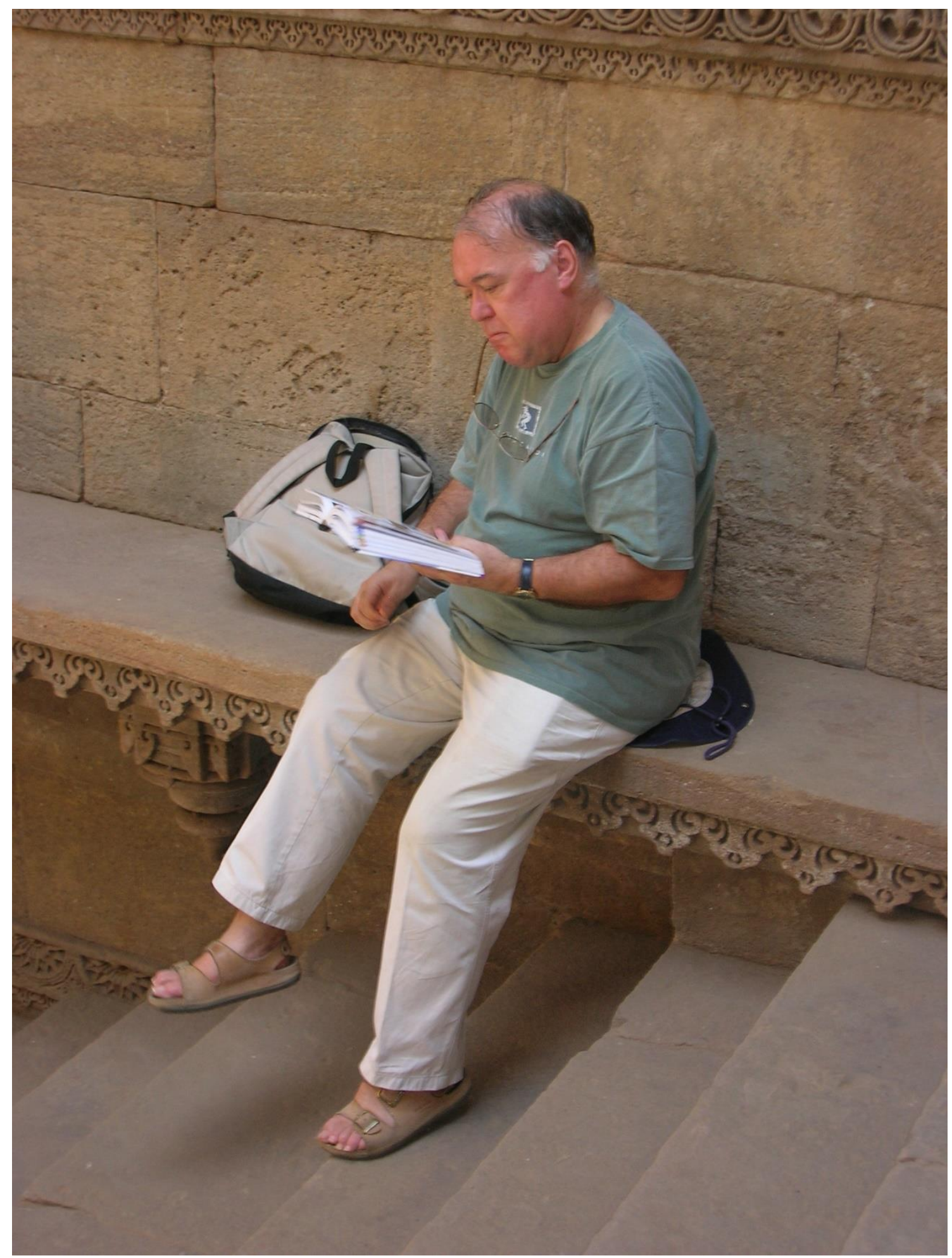

India 2007 C Ingrid Davis 
Coolabah, $N r$ 28, 2020, ISSN 1988-5946, Observatori: Centre d'Estudis Australians $i$ Transnacionals / Observatory: Australian and Transnational Studies Centre,

Universitat de Barcelona

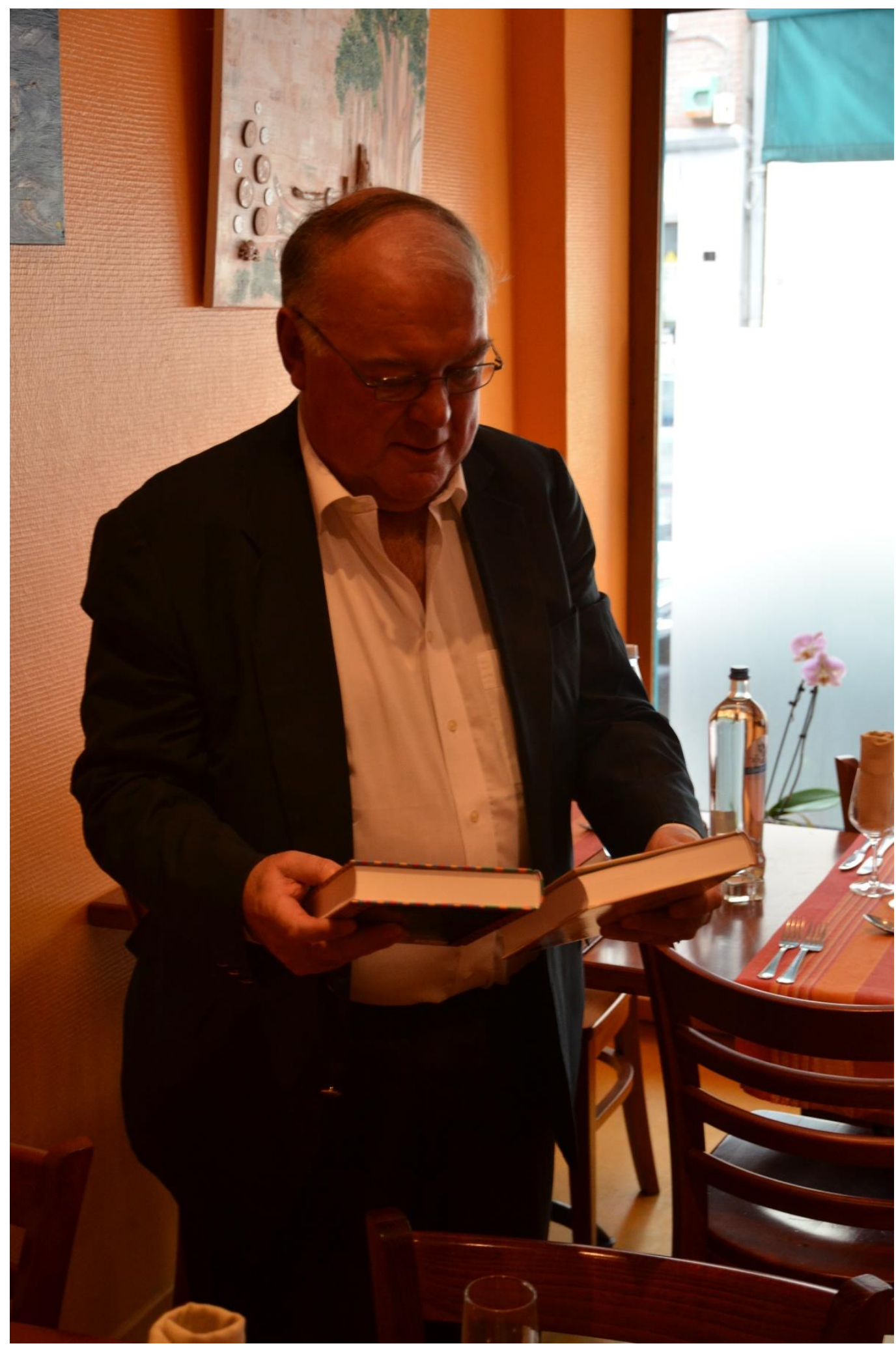

Festschrift Event 2012 (C) Ingrid Davis 
Coolabah, $N r$ 28, 2020, ISSN 1988-5946, Observatori: Centre d'Estudis Australians $i$ Transnacionals / Observatory: Australian and Transnational Studies Centre,

Universitat de Barcelona

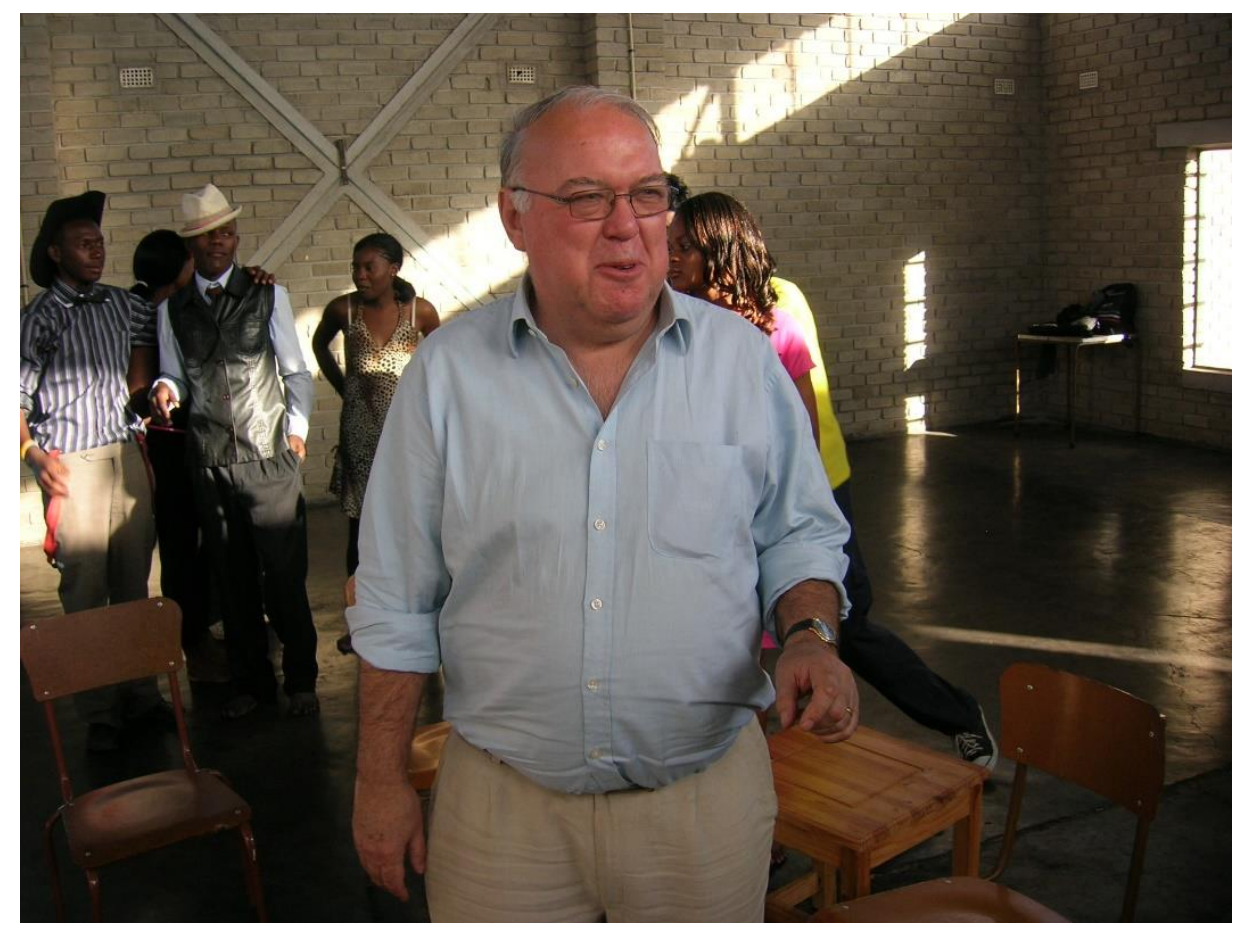

Zimbabwe 2012 (C) Ingrid Davis

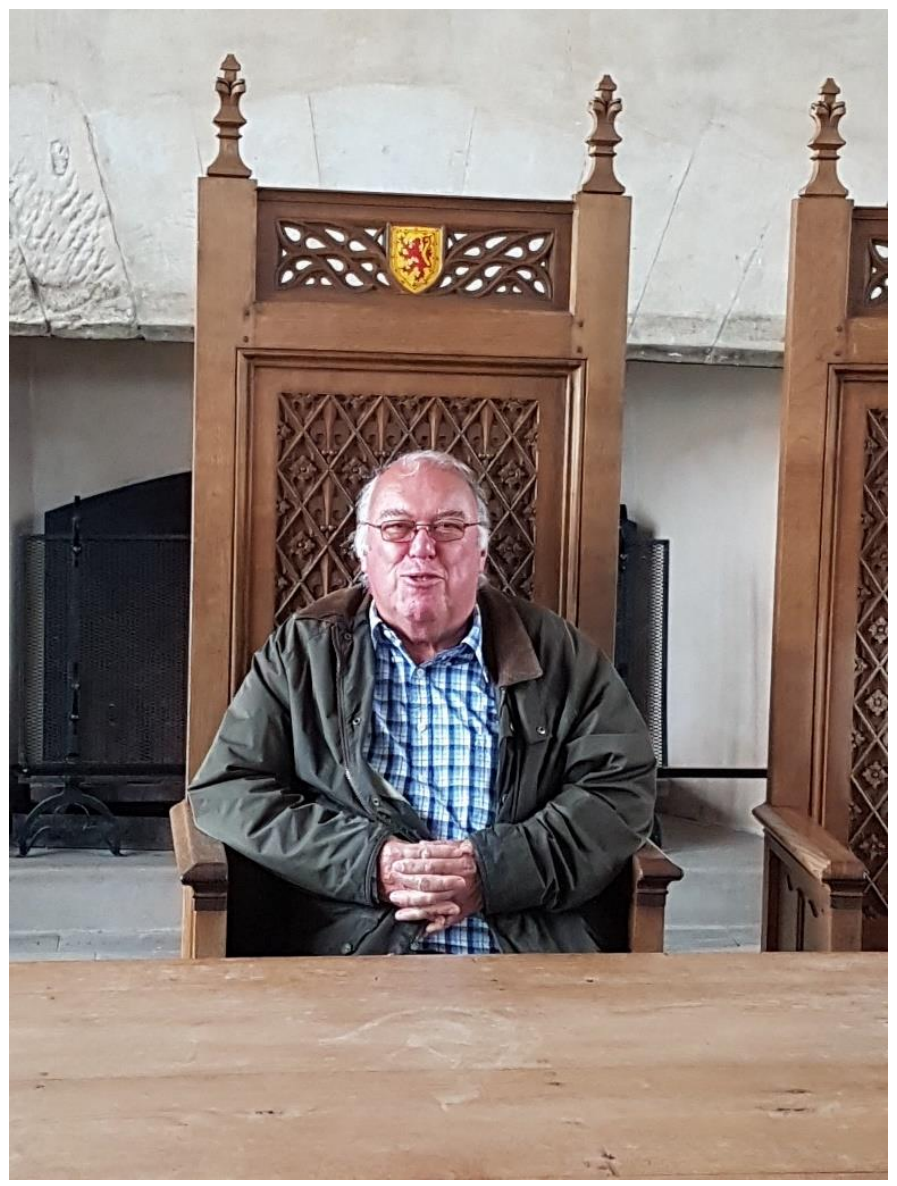

Stirling Castle 2017 C Ingrid Davis 